\title{
PENGARUH KECEPATAN ARUS AIR DALAM KOLAM TERHADAP TEKSTUR DAGING IKAN MAS
}

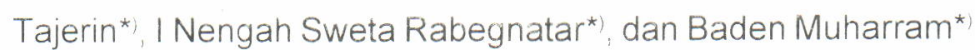

\begin{abstract}
ABSTRAK
Dalam rangka perbaikan mutu daging ikan mas, telah dilakukan penelitian untuk mengetahui pengaruh kecepatan arus air dalam kolam terhadap tekstur daging ikan mas di kolam percobaan Instalasi Penelitian Perikanan Air Tawar di Cijeruk, Bogor.

Ikan uji yang digunakan dalam penelitian ini adalah ikan mas ukuran 100 g/ekor dengan perlakuan kecepatan arus air yang berbeda. Tekstur daging ikan mas ditentukan menggunakan parameter tekstur $(\mathrm{kg} / \mathrm{mm})$ yang merupakan hasil bagi dari nilai kekerasan $(\mathrm{kg})$ dan kekenyalan $(\mathrm{mm})$. Rancangan percobaan yang dipergunakan adalah Rancangan Acak Lengkap (RAL) dengan tiga perlakuan yaitu kolam air tenang, kolam air mengalir dan kolam air deras, masing-masing perlakuan dengan tiga ulangan.

Hasil penelitian menunjukkan bahwa perlakuan kecepatan arus air memberikan pengaruh positif yang nyata $(p<0,05)$ terhadap tekstur daging ikan mas, terutama karena mampu meningkatkan proporsi otot merah, fungsi glikogen dan laktat otot dalam pembentukan energi, dan kadar protein otot dari fraksi albumin dan skleroprotein serta menurunkan kadar protein otot dari fraksi globulin dan kadar lemak dalam daging. Pengaruh tersebut disebabkan oleh perubahan proporsi otot miotomi terutama otot merah dan otot putih, konsentrasi glikogen otot dan laktat otot, protein otot, dan kadar lemak dalam daging.
\end{abstract}

ABSTRACT: The effect of water current rates in ponds on flesh texture of common carp. By: Tajerin, I Nengah Sweta Rabegnatar, and Baden Muharram

In attempt to improve the quality of common carp flesh, a research has been carried out to determine the effects of water current rates in ponds on the texture of common carp flesh.

The experimental fish used was common carp of $100 \mathrm{~g}$ each. The treatments were different rates of water current. The flesh texture was determined using texture parameter $(\mathrm{kg} / \mathrm{mm})$, expressed as the ratio of hardness value $(\mathrm{kg})$ and elasticity value $(\mathrm{mm})$. The experimental design used was Complete Randomized Design with three treatments and three replicates.

Result of the research showed that the rates of water current gave significant effects $(p<0.05)$ on texture of common carp flesh, especially to increase red muscle proportion, glycogen function and muscle lactate in energy formation, and muscle protein content from albumin and scleroprotein fractions, as well as to decrease muscle protein from globulin fraction and fat content in flesh. The effects were due to changes in the myotomical proportion (especially red muscle and white muscle), concentrations of muscle glycogen and lactate, muscle protein, and the concentration of fat in the flesh.

KEYWORDS : water current, common carp, flesh texture.

\section{PENDAHULUAN}

Ikan memerlukan energi untuk menopang proses hidupnya, terutama untuk fungsi fisiologis yang vital seperti pertumbuhan, reproduksi, pemeliharaan, dan aktivitas fisik (berenang). Masukan energi pakan pada ikan mas digunakan untuk pertumbuhan dan reproduksi sebanyak $32,6 \%$, untuk pemeliharaan $6,7 \%$ dan untuk aktivitas fisik (berenang) 30,2\%. Sedangkan energi yang hilang bersama kotoran, urine dan ekskresi insang sebanyak 30,5\% (Ding \& Yingfeng, 1984)

Aktivitas fisik pada ikan akan berhubungan dengan jaringan ototnya terutama pada proporsi tipe miotomi otot merahnya. Ikan dengan aktivitas berenang yang intensif ternyata memiliki proporsi otot merah yang lebih banyak dibanding otot merah muda dan otot putih. Otot merah didominasi oleh kandungan senyawa NADPH-diaforase, sedangkan otot putih didominasi oleh kandungan Aktimiosin ATP-ase (Gill et al., 1989). Proporsi yang mencolok pada otot merah di bagian ekor ikan ternyata berhubungan dengan bagian tubuh lainnya yang menjadi lebih kenyal selama melakukan aktivitas berenang (Boddeke et al., 1959; Mosse \& Hudson, 1977; Bruoghton et al., 1981). Lipas air (Rutilus rutilus) dari habitat dengan air deras memiliki

Peneliti pada Balai Penelitian Perikanan Air Tawar 
proporsi tipe miotomi otot merah yang lebih banyak dan berbeda nyata dibanding lipas dari spesies dan ukuran yang sama dari habitat dengan air tenang (Brolughton et al., 1981). Hal ini memberi indikasi bahwa proporsi dari variasi tipe miotomi otot (merah, merah muda dan putih) berubah-ubah menurut habitatnya

Jika aktivitas fisik pada ikan dilakukan secara terus-menerus (lebih intensif) dalam jangka waktu yang cukup maka dapat diharapkan jaringan otot akan berkembang dengan proporsi otot merah yang jauh lebih banyak, sehingga akan mendominasi komposisi jaringan penyusun daging dan tekstur daging ikan akan lebih kompak.

Ikan secara alamiah memiliki naluri menyukai arus air (Brett, 1984). Naluri ini mungkin didasarkan pengalaman bahwa makanan dan oksigen jauh lebih banyak terkandung dalam air yang mengalir. Mereka beranggapan, air yang mengalir berasal dari sumber pakan dan oksigen sehingga selalu berusaha mengejar sumber air. Untuk mencapai sumber air tentu diperlukan energi yang disalurkan ke otot-otot untuk berenang. Penggunaan energi (konsumsi oksigen) oleh ikan akan meningkat secara linier dengan aktivitas berenang yang semakin intensif (Bennett, 1978), dan akan meningkat cepat secara eksponensial tergantung ukuran tubuh dan temperatur air (Brett, 1972; Weatherley et al., 1982)

Preferensi konsumen ikan cenderung menghendaki ikan yang memiliki tekstur daging ikan yang lebih kompak dibanding dengan yang lembek. Kekompakan tekstur daging ikan banyak ditentukan oleh komposisi penyusunnya, yaitu jaringan otot, jaringan pengikat, dan jaringan lemak. Daging yang didominasi oleh unsur jaringan otot terutama dengan proporsi yang menonjol pada tipe miotomi otot merahnya akan lebih kompak teksturnya. Atas dasar ini maka salah satu upaya untuk meningkatkan kekompakan tekstur daging ikan dapat ditempuh dengan cara mengembangkan jaringan ototnya melalui peningkatan aktivitas fungsi otot dengan cara latihan (berenang) dalam air dengan kecepatan arus yang relatif tinggi (arus deras).

Usaha pembesaran ikan air tawar dapat dilakukan dalam beberapa cara antara lain dengan metodemetode yang dibedakan menurut kecepatan airnya, yaitu metode air tenang, air mengalir, dan air deras. Terdapat kecenderungan peningkatan tekstur daging ikan yang lebih kompak (kenyal) pada ikan dengan aktivitas berenang yang tinggi dan dilakukan secara intensif serta terus-menerus. Dengan demikian, peningkatan kekompakan (kekenyalan) tekstur daging ikan dapat dicapai dengan cara memeliharanya dalam air yang mengalir deras.

\section{BAHAN DAN METODE}

Ikan uji berupa ikan mas dengan bobot rata-rata $100 \mathrm{~g} / \mathrm{ekor}$, dipelihara dengan kepadatan $100 \mathrm{ekor} / \mathrm{m}$ dalam wadah bak beton dengan volume air $1 \mathrm{~m}^{3}$. Perbedaan kecepatan arus air merupakan perlakuan. Untuk menghasilkan perbedaan kecepatan arus aif tersebut dapat ditempuh dengan cara memberikan debit air yang berbeda pada satuan luas dan waktu yang sama. Dalam penelitian ini dilakukan tiga macam perlakuan dengan lama pemeliharaan tiga bulan Perlakuan pertama adalah kolam dengan kecepatan air yang tergolong rendah (kolam air tenang) dengan kecepatan arus air sebesar 0,10-0,15 m/det, perlakuan ke dua adalah kolam dengan kecepatan air yang tergolong sedang (kolam air mengalir) dengan kecepatan arus air sebesar 0,30-0,5 m/det., sedangkan perlakuan ke tiga adalah kolam dengan kecepatan air yang tergolong tinggi (kolam air deras) dengan kecepatan arus air sebesar 0,75-1,2 m/det. (Jangkaru, 1984). Kecepatan arus air pada ketiga perlakuan tersebut diupayakan tetap dengan cara mengatur besar-kecilnya debit air yang masuk ke masingmasing kolam perlakuan

Pemberian ransum harian pada ikan berupa pakan komersial sebanyak 3\% dari bobot badan. Sedangkan frekuensi pemberian pakan lima kali per hari dengan selang waktu dua jam yaitu pada pukul 08.00, 10.00 12.00,14.00, dan 16.00 WIB (Jangkaru, 1974) Ransum diberikan dengan cara menebarkannya pada tempat tertentu dari wadah penelitian. Sedangkan penimbangan dan penyesuaian ransum dilakukan setiap 2 minggu sekali dengan jumlah pakan sebanyak $3 \%$ dari bobot tubuh ikan

Adaptasi ikan uji terhadap lingkungan penelitian dan ransum yang dilakukan selama satu minggu sebelum penelitian (Steffens, 1981). Kondisi lingkungan seperti suhu air sebesar $23^{\circ} \mathrm{C}$ diupayakan tetap Oksigen terlarut, suhu air, $\mathrm{NH}_{3}$ terlarut, $\mathrm{CO}_{2}$ bebas $\mathrm{pH}$, dan alkalinitas air diukur seminggu sekali, yaitu setiap satu jam sebelum pemberian pakan pada pagi hari dan satu jam setelah pemberian pakan sore hari

Pengamatan parameter tingkat kekompakan tekstur daging ikan menggunakan metode pengukuran secara objektif dengan alat ukur teksturometer instron tipe Warner Bratzler meat shear yang akan menghasilkan grafik dengan satu titik puncak nilai kekerasan dengan satuan $\mathrm{kg}$ dan nilai kekenyalan dengan satuan $\mathrm{mm}$. Rasio/perbandingan antara kekerasan dan elasitas merupakan nilai tekstur daging ikan yang diukur. Nilai tekstur untuk masing-masing daging ikan merupakan rata-rata nilai tekstur daging dari tiga bagian badan ikan yaitu bagian belakang sampai sirip dada, bagian depan sampai sirip ekor, 
dan bagian belakang sampai sirip anus (Gill et al. 1989). Pengamatan tekstur dan proksimat dagirig ikan dilakukan setiap bulan, sedangkan pengamatan biokimia otot (khususnya kandungan glikogen dan laktat) dan proporsi tipe miotomi jaringan otot dilakukan pada akhir penelitian.

Pengamatan proporsi tipe miotomi jaringan otot dilakukan dengan prosedur sebagai berikut: ikan uji dibunuh menggunakan tricaine methanesulphonate (MS 222), ditimbang bobot dan diukur panjangnya. Sampel otot ikan diambil dari 3 bagian badan ikan, yaitu bagian belakang sampai sirip dada, bagian depan sampai sirip ekor, dan bagian belakang sampai sirip anus. Sampel otot dari masing-masing bagian badan ikan tersebut diambil dari potongan melintang otot yang diperoleh menggunakan alat "Tissue-Tek II O.C. T." dan didinginkan hingga $-160^{\circ} \mathrm{C}$ menggunakan nitrogen cair selama 10-15 detik. Selanjutnya ditempatkan dalam alat pendingin selama 1 jam pada suhu $-25^{\circ} \mathrm{C}$. Proporsi relatif dari otot merah dan putih (merupakan persentase dari total penampang melintang otot) pada 3 bagian badan yang berbeda tersebut diduga menggunakan alat ukur "Apple II microcomputer". Seluruh pengamatan terhadap parameter dalam penelitian ini dilakukan di Laboratorium Kimia Terpadu, Institut Pertanian Bogor. Analisis data dilakukan dengan uji sidik ragam (anova) untuk mengetahui pengaruh perlakuan, dan dilanjutkan dengan uji Duncan bila terdapat perbedaan yang nyata antar perlakuan (Duncan, 1977).

\section{HASIL DAN BAHASAN}

Pengaruh yang ditimbulkan oleh kecepatan arus air yang berbeda terhadap tekstur daging ikan mas yang dipelihara di kolam dalam penelitian ditinjau dari dua aspek, yaitu (1) aspek objektif tekstur, dan (2) aspek jaringan dan komponen biokimiawi otot.

\section{Aspek Objektif Tekstur}

Hasil penelitian menunjukkan bahwa perlakuan kecepatan arus air yang berbeda (kolam air tenang, kolam air mengalir dan kolam air deras) memberikan pengaruh yang nyata $(p<0,05)$ terhadap nilai ratarata tekstur daging ikan mas. Dari Tabel 1 diketahui bahwa nilai rata-rata tekstur daging ikan mas yang dipelihara di kolam air deras ternyata tertinggi dibandingkan dengan yang dipelihara di kolam air mengalir dan kolam air tenang. Selama pemeliharaan 12 minggu nilai rata-rata tekstur daging ikan mas masih menunjukkan kecenderungan yang meningkat Pada akhir penelitian (12 minggu pemeliharaan) terlihat bahwa nilai rata-rata tekstur daging ikan mas di kolam air deras mencapai $0,45 \mathrm{~kg} / \mathrm{mm}$, sedangkan di kolam air mengalir mencapai $0,38 \mathrm{~kg} / \mathrm{mm}$, dan di kolam air tenang hanya mencapai $0,25 \mathrm{~kg} / \mathrm{mm}$.

Pada Tabel 1 terlihat bahwa sampai dengan masa perneliharaan 12 minggu ternyata terkstur daging ikan mas pada perlakuan kolam air deras (KAD) adalah yang terbaik karena memiliki nilai rata-rata tekstur yang lebih tinggi dibanding pada perlakuan kolam air mengalir dan kolam air tenang. Tekstur daging ikan pada perlakuan kolam air tenang ternyata paling rendah

Bila dilihat berdasarkan laju peningkatannya dengan nilai rata-rata tekstur daging ikan mas sebelum perlakuan $(0,12 \mathrm{~kg} / \mathrm{mm})$ maka perlakuan kolam air deras menunjukkan kecenderungan yang meningkat cepat sampai dengan minggu ke-4, kemudian meningkat lambat sampai dengan minggu ke-8 dan selanjutnya kembali meningkat cepat sampai dengan minggu ke-12. Pada perlakuan kolam air mengalir, kecenderungan peningkatan terjadi sampai dengan minggu ke-12, meskipun dengan persentase perubahan yang lebih rendah dibanding perlakuan kolam air deras. Sebaliknya perlakuan kolam air tenang memiliki kecenderungan yang berlawanan dengan kolam air deras. Dari Tabel 1 terlihat bahwa perkembangan tekstur daging ikan mas untuk ketiga perlakuan menjadi perbedaan. Perlakuan kolam air deras memiliki pola peningkatan yang semakin bertambah, dan perlakuan kolam air mengalir memiliki pola peningkatan yang cenderung linier. Sedangkan

Tabel 1. Nilai rata-rata tekstur daging ikan mas $(\mathrm{kg} / \mathrm{mm})$ yang dipelihara di kolam dengan kecepatan air yang berbeda selama 12 minggu

Table 1. Average value of common carp flesh texture $(\mathrm{kg} / \mathrm{mm})$ reared in different rates of water inflow for 12 weeks

\begin{tabular}{cccc}
$\begin{array}{c}\text { Lama pemeliharaan (minggu) } \\
\text { Rearing period (weeks) }\end{array}$ & $\begin{array}{c}\text { Kolam air tenang } \\
\text { Stagnant waters pond }\end{array}$ & $\begin{array}{c}\text { Kolam air mengalir } \\
\text { Flowing water pond }\end{array}$ & $\begin{array}{c}\text { Kolam air deras } \\
\text { Running water pond }\end{array}$ \\
\hline 4 & 0.13 & 0.19 & 0.28 \\
8 & 0.24 & 0.27 & 0.31 \\
12 & 0.25 & 0.38 & 0.45 \\
\hline
\end{tabular}


Tabel 2. Proporsi jenis otot ikan mas (\%) yang dipelihara di kolam dengan kecepatan arus air yang berbeda selama 12 minggu

Table 2. The proportion of common carp muscle types (\%) reared in different rates of pond water inflow for 12 weeks

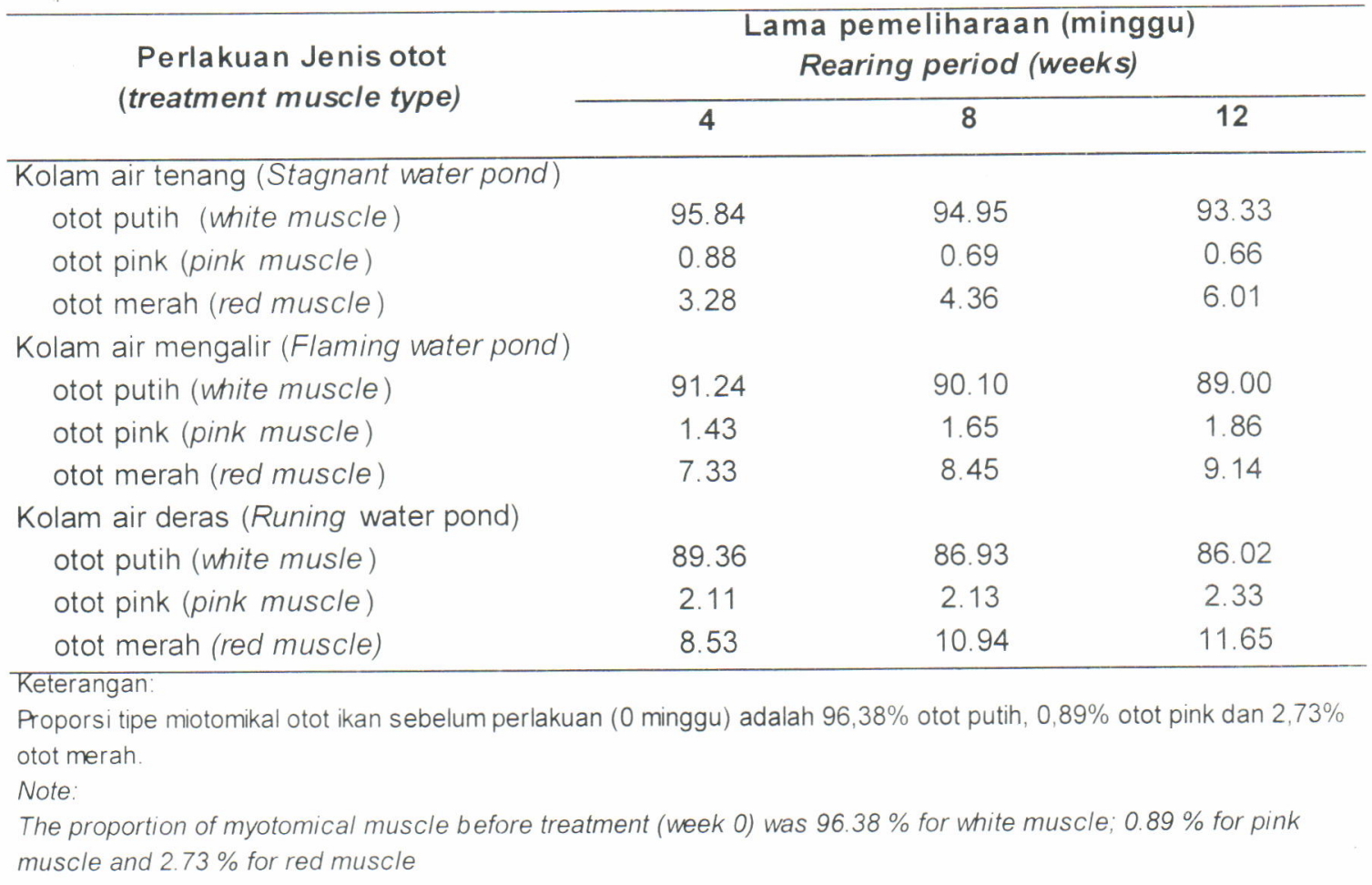

perlakuan kolam air tenang memiliki pola yang berlawanan dengan perlakuan kolam air deras, yaitu memiliki pola peningkatan yang semakin berkurang.

\section{Aspek Jaringan dan Biokimiawi Otot}

\section{Proporsi Tipe Myotomi Jaringan Otot}

Tekstur daging ikan terkait erat dengan jaringan otot. Jaringan ini secara parsial maupun simultan bersama dengan jaringan pengikat dan jaringan lemak akan menentukan tingkat kekompakan (kekenyalan) tekstur daging, karena daging ikan tersusun dari ketiga jaringan tersebut (Zaitsev et al., 1969). Proporsi ketiga otot tersebut dalam daging ikan untuk masing-masing perlakuan tertera pada Tabel 2 .

Otot merah pada ikan terdapat di sepanjang sisi badan di bawah kulit, sedangkan otot putih terdapat di seluruh tubuh selain di sepanjang bagian samping. Kedua otot tersebut dihubungkan oleh otot merah muda yang terdapat di seluruh tubuh ikan. Dari Tabel 2 diketahui bahwa bagian terbesar proporsi dari penampang melintang daging ikan terdiri atas otot putih yaitu berkisar antara 86-96 \%, otot merah berkisar antara 3-12 \%, dan hanya sebagian kecil otot merah muda yaitu berkisar antara $0,7-2 \%$. Otot merah (gelap) terdapat di sepanjang sisi badan di bawah kulit. sedangkan otot putih (terang) terdapat di seluruh tubuh selain sepanjang bagian samping

Dari hasil analisis diketahui bahwa perlakuan kecepatan air berpengaruh nyata terhadap perubahan proporsi otot merah $(p<0,01)$ dan otot putih $(p<0,05)$ daging ikan mas, sedangkan terhadap otot merah muda tidak berpengaruh nyata $(p>0,05)$. Dengan demikian diperoleh indikasi bahwa perubahan proporsi otot merah dan otot putih mempengaruhi nilai ratarata tekstur daging ikan mas.

Bila Tabel 1 dan 2 dihubungkan terlihat adanya kecenderungan atau arah yang berbeda pada hubungan antara perkembangan tekstur daging ikan dengan perubahan proporsi tipe miotomikal otot merah dan otot putih. Kecenderungan hubungan positif terdapat antara perkembangan tekstur daging ikan dengan perubahan proporsi otot merah, sedangkan dengan perubahan proporsi otot putih terjadi kecenderungan hubungan negatif. Dengan demikian diketahui bahwa ternyata meningkatnya nilai rata-rata tesktur daging ikan mas diikuti oleh bertambahnya proporsi otot merah dan berkurangnya proporsi otot putih. Temuan ini sejalan dengan hasil penelitian yang dilakukan Gill et al. (1989) dan Sanger et al. (1988) terutama dengan perubahan yang terjadi pada proporsi otot merahnya 
Tabel 3. Kadar lemak dalam daging ikan mas (\%) untuk masing-masing perlakuan selama 12 minggu

Table 3. Fat content of common carp flesh (\%) of each treatment during 12-week rearing period

\begin{tabular}{cccc}
\hline \multirow{2}{*}{$\begin{array}{c}\text { Lama pemeliharaan (minggu) } \\
\text { Rearing period (weeks) }\end{array}$} & \multicolumn{3}{c}{$\begin{array}{c}\text { Perlakuan kecepatan arus air } \\
\text { Treatment water current }\end{array}$} \\
\cline { 2 - 4 } & $\begin{array}{c}\text { Kolam air tenang } \\
\text { Stagnant water pond }\end{array}$ & $\begin{array}{c}\text { Kolam air mengalir } \\
\text { Flowing water pond }\end{array}$ & $\begin{array}{c}\text { Kolam air deras } \\
\text { Running water pond }\end{array}$ \\
\hline 4 & 18.86 & 16.77 & 13.22 \\
8 & 14.31 & 14.48 & 12.06 \\
12 & 13.74 & 11.23 & 9.2 \\
\hline
\end{tabular}

Keterangan: Kadar lemak dalam daging sebelum perlakuan (aw al) $=20,46 \%$

Note: $\quad$ Fat content before treatment was $20.46 \%$

Kedua hasil penelitian tersebut menunjukkan bahwa meningkatnya aktivitas berenang pada ikan akan berpengaruh terhadap meningkatnya proporsi otot merah dan menurunnya proporsi otot putih.

\section{Kandungan Lemak dalam Daging}

Secara relatif otot merah mengandung lemak yang lebih tinggi dan protein yang lebih rendah, sebaliknya otot putih mengandung protein yang lebih tinggi dan lemak yang lebih rendah dibanding otot merah (Sanger, 1992). Namun demikian meningkatnya proprosi otot merah pada daging ikan uji tidak berarti bahwa kandungan lemak dari seluruh bagian daging tersebut akan meningkat pula karena hasil penelitian justru menunjukkan tingginya nilai rata-rata tekstur daging dikuti oleh meningkatnya proporsi otot merah pada daging ikan tersebut. Hal ini disebabkan karena bagian terbesar dari kandungan lemak dalam daging ikan bukan dari bagian otot merah tetapi dari bagian jaringan lemak. Menurut Zaitsev et al. (1969) daging ikan tersusun dari jaringan otot, jaringan pengikat dan jaringan lemak. Jaringan pengikat dan jaringan lemak berfungsi menyatukan serat-serat jaringan otot. Interaksi ketiga jaringan tersebut akan mempengaruhi sifat tekstur daging ikan.

Hasil penelitian menunjukkan bahwa terdapat hubungan negatif yang sangat kuat $(r=-0,97)$ antara tekstur daging dengan kadar lemak dalam daging ikan uji. Nilai rata-rata tekstur daging ikan mas menurun dengan adanya peningkatan kadar lemak dalam daging. Hubungan ini tersirat dalam persamaan $y=$ $0,604-0,023 \times(y=$ nilai rata-rata tekstur daging ikan dan $x=$ kadar lemak dalam daging ikan). Selain itu dari Tabel 3 diketahui bahwa ternyata kadar lemak dalam daging berbeda nyata $(p<0,05)$ untuk masingmasing perlakuan kecepatan arus air.

Berdasarkan kedua hasil analisis di atas maka diketahui peningkatan kecepatan arus air dalam kolam akan menurunkan kadar lemak dalam daging dan selanjutnya akan meningkatkan tekstur daging ikan mas. Berkurangnya kadar lemak dalam daging untuk kolam dengan kecepatan arus air yang semakin tinggi (seperti kolam air deras) menunjukkan adanya penggunaan lemak pakan untuk kebutuhan energi semakin tinggi (di samping yang diperoleh dari protein pakan), terutama yang digunakan oleh tubuh ikan untuk kontraksi otot selama melakukan aktivitas berenang yang semakin intensif di samping yang diperolehnya dari protein.

Dengan menggunakan pola pemberian ransum pakan secara satiation sementara kebutuhan energi untuk kontraksi otot terus meningkat selama melakukan aktivitas berenang yang semakin intensif, tentunya perlakuan kecepatan arus air akan mempengaruhi retensi protein, retensi lemak dan ukuran tubuh ikan mas uji, seperti terlihat pada Tabel 4.

Berdasarkan hasil uji BNT ternyata retensi protein untuk perlakuan kolam air tenang dan kolam air mengalir tidak berbeda nyata $(p>0,05)$, tetapi keduanya berbeda nyata dengan perlakuan kolam air deras (Tabel 4). Hal ini menunjukkan bahwa efektivitas pakan sama pada perlakuan kolam air tenang dan kolam air mengalir, tetapi keduanya menunjukkan efektivitas pakan yang berbeda dengan perlakuan kolam air deras. Menurut Viola \& Rappaport (1979), retensi protein dapat menjadi indikator efektivitas pakan. Retensi protein yang terbesar terdapat pada perlakuan kolam air mengalir yaitu sebesar $32,53 \%$.

Tabel 4 menunjukkan bahwa ternyata perlakuan kecepatan arus air yang berbeda memberikan pengaruh berbeda nyata $(p>0,05)$ terhadap retensi lemak ikan uji. Ikan mas yang dipelihara dengan perlakuan kolam air deras memiliki retensi lemak yang tertinggi yaitu sebesar $86,21 \%$. Selanjutnya retensi lemak ikan uji menurun sesuai dengan rendahnya kecepatan arus air, yaitu $56,37 \%$ untuk perlakuan kolam air mengalir dan $29,82 \%$ untuk perlakuan kolam air tenang. Retensi lemak perlakuan kolam air deras yang lebih besar dari $100 \%$ menunjukkan bahwa kadar lemak pakan yang ada belum mencukupi kebutuhan 
Tabel 4. Retensi protein (\%), retensi lemak (\%), dan ukuran tubuh ikan mas pada akhir percobaan

Table 4. Protein retention (\%), fat retention (\%), and common carp body size of each treatment at the end of experiment

\begin{tabular}{lcccc}
\hline \multirow{2}{*}{\begin{tabular}{l} 
Perlakuan (Treatment) \\
\cline { 2 - 5 }
\end{tabular}} & $\begin{array}{c}\text { Prote in } \\
\text { Protein }\end{array}$ & $\begin{array}{c}\text { Lemak } \\
\text { Fat }\end{array}$ & $\begin{array}{c}\text { Panjang total }(\mathbf{c m}) \\
\text { Total Length }(\mathbf{c m})\end{array}$ & $\begin{array}{c}\text { Bobot tubuh (g) } \\
\text { Weight }(\mathbf{g})\end{array}$ \\
$\begin{array}{l}\text { Kolam air tenang } \\
\text { Stagnant water pond } \\
\text { Kolam air mengalir }\end{array}$ & $30.11 \mathrm{~b}$ & $29.82^{\mathrm{a}}$ & $22.78 \pm 1.90$ & $216.72 \pm 45.09$ \\
$\begin{array}{l}\text { Flowing water pond } \\
\text { Kolam air deras } \\
\text { Running water pond }\end{array}$ & $32.53 \mathrm{~b}$ & $56.37^{\mathrm{b}}$ & $23.11 \pm 2.48$ & $204.89 \pm 47.81^{\mathrm{b}}$ \\
\hline
\end{tabular}

angka dalam kolom yang sama diikuti huruf super script yang sama tidak berbeda nyata (Values in the column followed with the same superscript are not significantly different) $(P>0.05)$

lemak tubuh ikan, sehingga tubuh perlu menyintesisnya dari senyawa non-lemak melalui proses biokonversi dari karbohidrat dan protein (Ganong, 1980; Ogino et al., 1976)

Retensi lemak yang lebih tinggi dibanding retensi protein terutama pada perlakuan kolam air deras (Tabel 4) mungkin disebabkan protein pakan yang diabsorbsi lebih banyak dirombak untuk menghasilkan energi (Jangkaru, 1974). Jika kandungan energi pakan rendah maka sebagian besar protein pakan akan dikatabolisme untuk memenuhi kebutuhan energi ikan. Karena banyaknya protein yang dirombak digunakan untuk menghasilkan energi maka berakibat pada jumlah protein yang digunakan untuk pembentukan jaringan tubuh menjadi rendah (Lovell, 1989).

Pengaruh perlakuan kecepatan arus air yang berbeda terhadap retensi lemak ternyata berimbas pada ukuran ikan (Tabel 4). Hal ini terlihat dari adanya bobot tubuh ikan uji yang berbeda nyata $(p<0,05)$ antara perlakuan kolam air tenang, mengalir, dan deras. Demikian juga terhadap panjang total ikan meskipun tidak menunjukkan adanya beda nyata, namun ada kecenderungan bahwa semakin tinggi kecepatan arus air yang digunakan maka panjang total ikan makin meningkat. Bila panjang total dan bobot tubuh ikan uji pada Tabel 3 dihubungkan maka terlihat ikan yang semakin langsing dengan meningkatnya penggunaan kecepatan arus air dalam kolam yang dicobakan.

\section{KOMPONEN BIOKIMIAWI OTOT}

\section{Glikogen dan Laktat Otot}

Perlakuan kecepatan arus air akan mendorong ikan untuk melakukan aktivitas berenang. Energi untuk berkontraksi otot selama melakukan aktivitas berenang pada ikan berasal dari hidrolisis ATP. Energi ini diperlukan untuk menggerakkan aktin terhadap miosin dan juga untuk memompakan kembali kalsium ke dalam retikulum endoplasmik (Johnston \& Goldspink, 1972).

ATP yang digunakan untuk kontraksi tadi dibentuk kembali dengan menggunakan fosfokreatin melalui reaksi-reaksi yang cepat untuk membentuk ATP dari senyawa-senyawa lain yang mempunyai ikatan yang kaya energi. Namun bila tidak ada oksigen, ATP dapat dibentuk dari glukosa yang hanya akan menghasilkan dua molekul ATP dan dua molekul asam laktat dari satu molekul glukosa. Dengan demikian glukosa dapat dioksidasi secara lengkap menjadi air dan $\mathrm{CO}_{2}$. Hasil bersihnya adalah berupa pembentukan 38 molekul ATP. Bila reaksi-reaksi ini dimulai dari glikogen akan terbentuk satu molekul ATP lagi untuk tiap oksidasi lengkap glukosa (Sadikin, 1994)

Komponen biokimiawi yang terkait dengan kebutuhan energi untuk kontraksi otot tersebut seperti senyawa glikogen dan laktat dibahas dalam penelitian ini. Secara rinci konsentrasi kedua senyawa tersebut untuk masing-masing perlakuan tertera pada Tabel 5

Tabel 5 menunjukkan bahwa konsentrasi glikogen otot pada bagian otot merah untuk ketiga perlakuan kecepatan arus air dalam kolam (kolam air tenang, kolam air mengalir, dan kolam air deras) ternyata berbeda nyata $(p<0,05)$, namun pada bagian otot putih pada perlakuan kolam air tenang dan kolam air mengalir tidak berbeda nyata $(p>0,05)$ dan keduanya berbeda nyata $(p<0,05)$ terhadap konsentrasi glikogen otot merah pada perlakuan kolam air deras. Perbedaan pengaruh tersebut terhadap otot merah dan otot putih disebabkan peranan otot merah yang lebih dominan dalam melakukan kontraksi otot seperti dalam melakukan aktivitas berenang yang didukung oleh terjadinya kondisi "pemuatan karbohidrat". Otot mengandung glikogen dalam jumlah yang relatif sedikit namun lebih konstan. Jumlah glikogen otot hanya akan menurun sesudah kerja otot yang lama 
Tabel 5. Rata-rata konsentrasi kandungan laktat pada miotomikal otot merah dan otot putih ikan mas untuk masing-masing perlakuan pada akhir penelitian (minggu ke 12)

Table 5. Average concentration of lactate in red and white myotomical muscles of each treatment at the end of experiment (week 12)

\begin{tabular}{|c|c|c|c|c|}
\hline \multirow{2}{*}{$\begin{array}{l}\text { Perlakuan } \\
\text { Treatment }\end{array}$} & \multicolumn{2}{|c|}{ Glycogen (mg/100g) } & \multicolumn{2}{|c|}{ Lactate $(\mathrm{mg} / 100 \mathrm{~g})$} \\
\hline & $\begin{array}{l}\text { Otot merah } \\
\text { Red muscle }\end{array}$ & $\begin{array}{c}\text { Otot putih } \\
\text { White muscle }\end{array}$ & $\begin{array}{l}\text { Otot merah } \\
\text { Red muscle }\end{array}$ & $\begin{array}{c}\text { Otot putih } \\
\text { White muscle }\end{array}$ \\
\hline $\begin{array}{l}\text { Kolam air tenang } \\
\text { Stagnant water pond }\end{array}$ & $3467^{a}$ & $1303^{b}$ & $100.12^{a}$ & $48.90^{\mathrm{ab}}$ \\
\hline $\begin{array}{l}\text { Kolam air mengalir } \\
\text { Flowing water pond }\end{array}$ & $2141^{b}$ & $1225^{b}$ & $154.29^{b}$ & $136,56^{\mathrm{a}}$ \\
\hline $\begin{array}{l}\text { Kolam air deras } \\
\text { Running water pond }\end{array}$ & $1920^{c}$ & $1002^{a}$ & $237.40^{\mathrm{ab}}$ & $240.80^{b}$ \\
\hline
\end{tabular}

Angka dalam kolom yang sama diikuti huruf super script yang sama tidak berbeda nyata (Values in the column followed with the same superscript are not significantly different) $(P>0.05)$

Bila ikan mengkonsumsi pakan yang kaya akan karbohidrat maka jumlah glikogen otot akan naik melampaui tingkatnya yang biasa yaitu $1 \%$, sehingga akan terjadi kondisi "pemuatan karbohidrat" (carbohydrate loading) pada ikan yang menyebabkan ikan akan mampu bertahan lama dalam melakukan aktivitas berenang (Johnston \& Goldspink, 1972).

Selanjutnya diketahui bahwa perlakuan kecepatan arus air yang berbeda ternyata hanya memberikan pengaruh berbeda nyata $(p<0,05)$ dalam hal konsentrasi laktat yang dikandung otot merah ikan yang dipelihara dalam kolam air tenang dan kolam air mengalir, sedangkan keduanya tidak berbeda nyata $(p>0,05)$ pada perlakuan kolam air deras. Sebaliknya konsentrasi laktat pada otot putih berbeda nyata $(P<0,05)$ antara perlakuan kolam air mengalir dan kolam air deras, sedangkan terhadap konsentrasi laktat ikan di kolam air mengalir tidak menunjukkan beda yang nyata $(p>0,05)$. Hal ini berkaitan dengan proses terbentuknya sumber energi yang utama bagi ikan untuk kontraksi otot cepat pada situasi di mana oksigen yang dikonsumsi ikan dalam konsentrasi yang relatif rendah seperti pada kolam air tenang dan kolam air mengalir dibandingkan dengan kolam air deras. Kondisi ini terlihat jelas pada perbedaan konsentrasi laktat otot putih, karena otot ini lebih banyak menunjukkan perannya dalam kontraksi otot secara cepat pada kondisi tiba-tiba dengan konsentrasi oksigen yang relatif rendah.

\section{Protein Otot}

Serabut otot ikan bersatu membentuk lempenganlempengan yang tersusun secara sentris dari depan ke belakang, sedangkan otot rangka ikan dibagi dalam sejumlah segmen yang disebut miotomi yang dipisahkan oleh lembaran-lembaran tipis jaringan ikat yang disebut miokommata. Miokommata berfungsi sebagai jaringan yang memadu daya kontraksi serabut otot. Miotomi otot ikan berisi endomisium yang mengikat serabut otot. Serabut otot mengandung banyak miofibril yang tersusun paralel dan dihubungkan oleh sarkoplasma (Zaitsev et al., 1969). Daging ikan memiliki tiga tipe protein yaitu sarkoplasma, miofibrilar atau protein kontraktil dan stroma (Mosse et al., 1981).

Dari Tabel 3 diketahui bagian terbesar jenis protein daging ikan mas adalah protein miofibril (globulin), untuk ketiga perlakuan berkisar antara $64 \%-77 \%$, dengan bagian terbesar terdapat pada perlakuan kolam air deras yaitu sebesar $77,33 \%$. Sedangkan jenis protein sarkoplasma (albumin) berkisar antara $34 \%-19 \%$, dan sebagian kecil saja jenis protein stroma (skleroprotein) yang terkandung dalam daging ikan yaitu hanya berkisar antara $1 \%-3 \%$ saja.

Hasil analisis sidik ragam menunjukkan bahwa perlakuan kecepatan arus air yang dicobakan berpengaruh nyata $(p<0,05)$ terhadap kadar protein sarkoplasma, miofibrilar dan stroma (Tabel 6).

Dengan demikian pengaruh nyata perlakuan kecepatan arus air dalam kolam terhadap kadar protein sarkoplasma (globulin) dan miofibril menunjukkan bahwa perlakuan kolam air deras dapat meningkatkan nilai rata-rata tekstur daging ikan melalui pengaruhnya dan menurunkan kadar protein sarkoplasma meningkatkan kadar protein miofibril (bila dikaitkan dengan Tabel 1).

Miofibril mengandung protein miosin, aktin, aktomiosin, dan tropomiosin. Terang dan gelap yang tampak pada miofibril diakibatkan adanya miofilamen, yaitu protein yang berbentuk serabut halus. Otot merah didominasi oleh miofilamen yang tebal (gelap) yang mempunyai komponen utama miosin, sedangkan otot putih didominasi oleh miofilamen yang tipis (terang) yang memiliki komponen utama aktin (Mosse et al., 1981). Fraksi miosin merupakan komponen yang sangat menentukan dalam meningkatkan tekstur produk (Heruwati et al., 1995). 
Tabel6. Jenis dan kadar protein otot ikan mas (\%) yang dipelihara di kolam dengan kecepatan air yang berbeda selama 3 bulan

Table 6. Type and content of protein in common carp muscle (\%) reared in ponds with different flow water rate for 3 months

\begin{tabular}{lccc}
\hline \multicolumn{1}{c}{ Friksi } & $\begin{array}{c}\text { Kolam air tenang } \\
\text { Stagnant water pond }\end{array}$ & $\begin{array}{c}\text { Kolam air mengalir } \\
\text { Flowing water pond }\end{array}$ & $\begin{array}{c}\text { Kolam air deras } \\
\text { Running water pond }\end{array}$ \\
$\begin{array}{l}\text { Sarkoplasma \% globulin } \\
\text { Sarcoplasm globulin }\end{array}$ & $34,59^{\mathrm{a}}$ & $28,37^{\mathrm{b}}$ & $17,21^{\mathrm{c}}$ \\
$\begin{array}{l}\text { Miofibril \% albumin } \\
\text { Myofibril \% albumin }\end{array}$ & $64,50^{\mathrm{a}}$ & $69,41^{\mathrm{b}}$ & $79,33^{\mathrm{c}}$ \\
$\begin{array}{l}\text { Stroma \% (Skleroprotein) } \\
\text { Stroma \% Skleroprotein }\end{array}$ & $0,91^{\mathrm{a}}$ & $2,22^{\mathrm{b}}$ & $3,46^{\mathrm{c}}$ \\
\hline
\end{tabular}

Angka dalam kolom yang sama diikuti huruf super script yang sama tidak berbeda nyata (Values in the column followed with the same superscript are not significantly different) $(P>0.05)$

Pengaruh negatif protein sarkoplasma terhadap nilai rata-rata tekstur daging ikan menunjukkan bahwa dengan perlakuan kecepatan arus air di dalam kolam dapat mengurangi kadar protein sarkoplasma (globulin) yang dapat menurunkan tekstur suatu produk (Mosse et al., 1977).

Beda yang nyata antara perlakuan kolam air tenang, kolam air mengalir dan kolam air deras terhadap kadar protein stroma (skleroprotein) menunjukkan bahwa perlakuan kecepatan arus air dapat memberikan sumbangan nyata terhadap pembentukan jaringan ikat yang diperlukan dalam peningkatan nilai rata-rata tekstur daging ikan mas. Kelompok protein berfungsi sebagai jaringan pengikat dan disebut juga skleroprotein dengan komponen kolagen dan elastin, letaknya pada miokommata dan membran sel, dan berfungsi sebagai jaringan ikat (Mosse et al., 1977).

\section{KESIMPULAN}

Berdasarkan hasil dan bahasan dapat ditarik kesimpulan bahwa perlakuan kecepatan arus air dalam kolam efektif digunakan untuk meningkatkan kekompakan tekstur daging ikan mas, terutama karena mampu meningkatkan proporsi otot merah, meningkatkan fungsi glikogen dan laktat otot (otot merah dan putih) dalam pembentukan energi, menambah kadar protein otot dari friksi albumin dan skleroprotein, mengurangi kadar protein otot dari friksi globulin dan menurunkan kadar lemak dalam daging ikan.

\section{SARAN}

Berdasarkan permasalahan yang dijumpai selama dilakukan percobaan pemeliharaan maka dapat diajukan saran sebagai berikut:
1. Penelitian untuk mencari faktor-faktor yang mempengaruhi peningkatan tekstur ikan mas dan cara-cara untuk memperbaikinya perlu terus dilakukan dengan aspek kajian yang lebih luas dan tetap memperhatikan faktor peningkatan pertumbuhan terutama bobot tubuh ikan.

2. Penggunaan perlakuan kolam air deras dapat digunakan sebagai salah satu upaya bagi peningkatan kekompakan tekstur daging ikan mas, dengan cara pada tahap tertentu dipelihara dalam kolam arus tenang baru setelah mendekati panen dipelihara dalam kolam air deras. .

\section{DAFTAR PUSTAKA}

Bennett, A.F. 1978. Activity metabolism of the louver vertebrates. Ann. Rev. Physiol 8 40: 447-469

Bolddeke, R., Slijper E.J., and A.Van der Stell, 1959. Histological characteristics of the body musculature of fishes in connection with their molde of life. Koninklijke Ned. Acad. Van Hetenschappenser. 62:576

Brett, J.R. 1972. The respiratory metabolism and swimming performance of young sockeye salmon. Journal of the Fisheries Reserch Bolard of Canada. 21:1183-1226.

Bruoghton, N.M., G.Goldspink, and N.V. Jones. 1981 Histological difference in the lateral musculature of group roach, Rutilus rutilus (L.) from different habitats. J. Fish Biol. 18: 117-122.

Ding, L.M. and C. Yingfeng. 1994. Studies the energy partitioning in diet consumed by grass carp, Ctenopharyngodon idellus (C. et Va.). In De Silva, S.S. (eds.) Fish nutrition research in Asia. Proceedings of the Asian Fish Nutrition Workshop. Asian Fish Soc. Spec. Publ. 9, Manila, Philipines, Asian Fisheries Society. p: 49-55.

Duncan, O.D. 1977. Introduction to Structural Equation Models, Academic Press, New York. p 677-682. 
Ganong. W.F. 1980. Review of Medical Phisyiology Llange Medical Publications, Los Alltos, California, USA. 763pp

Gill, H.S., A.H. Weatherley, R. Lee, and D. Legere. 1989. Histochemical characterization of muscle of five teleost spesies. J. Fish Biol. p 34: 375-386.

Jangkaru, Z. 1974. Makanan Ikan. Correspondence Course Centre, Dit. Jen. Perik., Deptan., Jakarta. 72 pp

Jangkaru, Z. 1984. Pemeliharaan Ikan dalam Kolam Air Deras. CV Yasaguna. Jakarta. 50 p.

Johnston, I.A. and G.Goldspink. 1972. The effect of sustained swimming performance on the concentrations of glycogen and lactate occuring in the myotomial muscles and liver of the coalfish (Gadus virens L.). J. Mar. Biol. Ass. U.K. p 53: 17-26.

Lovell, T. 1989. Nutrient and Feeding of Fish. Van Nostrand Reinhold, New Yrok. 260pp.

Mosse, P.R.L. and R.C.L. Hudson 1977. The functional roles of different muscle fibre types identified in myotomes of marine teleosts; a behavioral, anatomical and histochemical study. J. Fish Biol. 11 417-430.

Heruwati, E.S., J.T. Murtini \& S. Rahayu. 1995. Pegaruh jenis ikan dan penambahan elastistitas surimi ikan air tawar. Jur. Penel. Perik. Indonesia. 1 (1) : 86-94.

Ogino, C.J., Y. Chiou \& T. Takeuchi. 1976. Protein Nutrition in Fish VI: Efect of diater energy sources on the utilization of proteins by rainbow trout and carp. Bull. Jap. Soc. Sci. Fish. 42 (2): 213-218.

Proceedings of The Asian Fish Nutrion Workshop. Asian Fish Soc. Spec. Publ. 9, Manila, Philipines, Asian Fisheries Society. p: 49-55.

Sadikin, M. 1996. Intisari Biokimia. CV Binarupa Aksara, Jakarta. P 56-174.

Sanger, A.M. 1992. Quantitative fine structural diversification of red and white muscle fibres in cyprinids. Environmental Biology of Fishes 33:97-104.

Steffens, W. 1981. Protein utillization by rainbow trout, Salmo gairdneri and Carp, Cyprinus carpio Linn. A Brief Review Aquaculture. 23:337-345.

Stickney, R.R. and R.T. Lovelll. 1977. Nutrition and Feeding of Channel Catfish. Bull. 218, Alabama Ag. Exp. Sta. Auburn Univ., Auburn, Alabama. 67p.

Viola, S. and U. Rappaport. 1979. The Extra Calorie Effect of Oil on Nutrition of Carp. Bamidgeh. 31(3):51-69.

Wetherley, A.H., Rogers, S.C., Pincock, D.G. and Patch, J.R. 1982. Oxygen consumtio in of active rainbow trout, Salmo gairdneri, derived from elelctromyolgrams obtained by radiotelemetry. J. Fish Biol. 20: 479-489.

Zaitsev, V., I. Kizevetter, L. Lagunov, T. Makarova, L. Minder and V. Podsevalov. 1969. Fish Curing and Processing, Mir Publisher, Moscow. 370 pp. 